\title{
Working
}

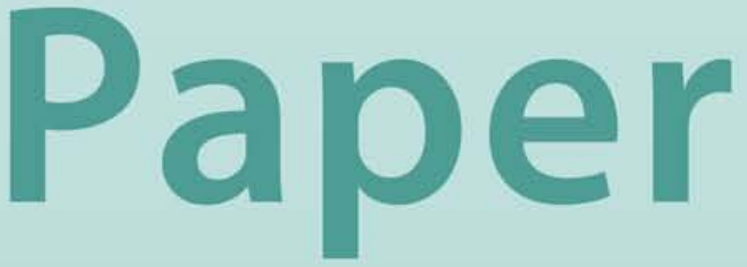


Regional Disparities and Transfer Policies in Russia: Theory and Evidence Era Dabla-Norris and Shlomo Weber 


\title{
IMF Working Paper
}

IMF Institute

\section{Regional Disparities and Transfer Policies in Russia: Theory and Evidence}

\author{
Prepared by Era Dabla-Norris and Shlomo Weber ${ }^{1}$ \\ Authorized for distribution by Eric V. Clifton
}

December 2001

\begin{abstract}
The views expressed in this Working Paper are those of the author(s) and do not necessarily represent those of the IMF or IMF policy. Working Papers describe research in progress by the author(s) and are published to elicit comments and to further debate.
\end{abstract}

In this paper we examine economic disparities across regions in Russia and offer a theoretical treatment of various transfer rules between different regions. We analyze the principle of partial equalization, which implies that the more depressed regions should be subsidized by the more advantaged regions, but, the burden on more prosperous regions should not be excessive. Although, contrary to the partial equalization principle, the gaps between the richer and poorer regions have widened since the transition, there are some signs that this trend could be reversed.

JEL Classification Numbers:H50; H72; H73; O52; O53

Keywords: Russia; regional disparities; horizontal imbalances; transfers

Author's E-Mail Address: edablanorris@imf.org; sweber@mail.smu.edu

\footnotetext{
${ }^{1}$ IMF and Southern Methodist University, respectively. The paper was initiated while the second author was visiting Fiscal Affairs Department of the International Monetary Fund. We wish to thank George Abed, Ehtisham Ahmad, Nadezhda Bikalova, Ke-Young Chu, Luc Leruth, John Norregaard and Vito Tanzi for stimulating discussions. This paper will be appearing in ed. M. Cuddy and R. Gekker (ed.) "Institutions and their Change in Transition Economies," (Ashgate 2002).
} 
Contents Page

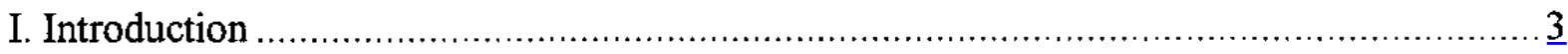

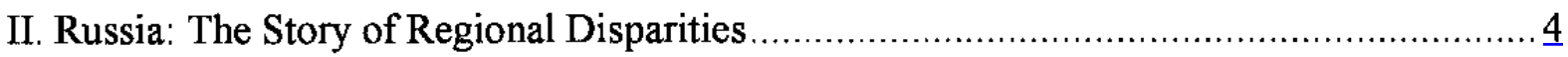

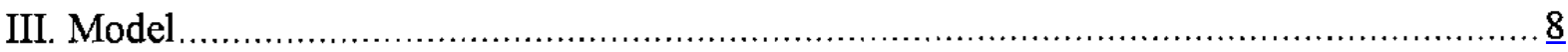

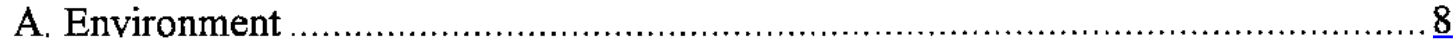

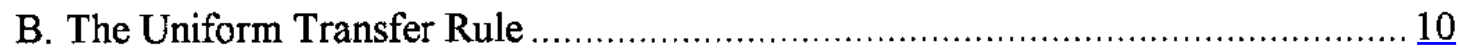

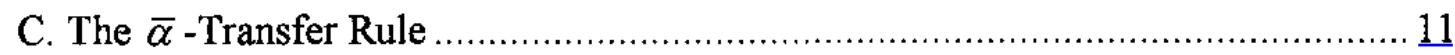

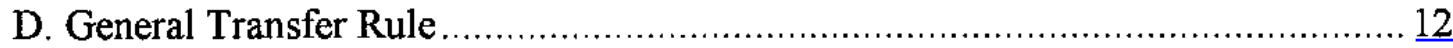

IV. Federal Government Responses to Regional Diversity and Disbursement Pattern of

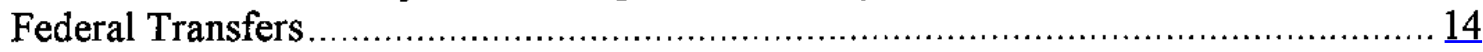

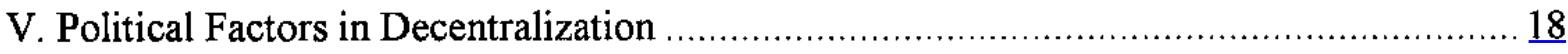

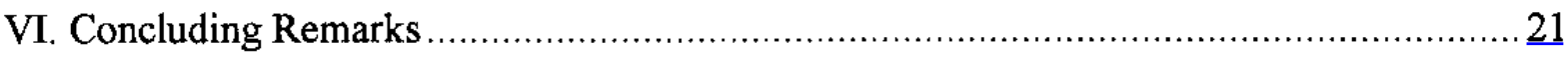

Text Tables

1. Regional Economic Disparities, 1992-1997 ……...................................................

2. Measures of Regional Fiscal Disparities: Per Capita Regional Revenue Collections,

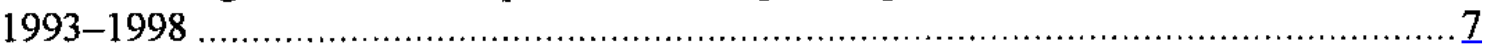

3. Concentration of Total Revenue Collections Among Oblast: Share of Total Revenues Collected by Selected Regions, 1993-1998 ………............................................

4. Measures of Horizontal Fiscal Imbalance: Per Capita Regional Expenditures,

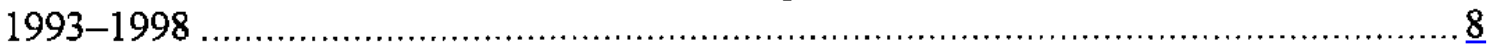

5. Indicators of Asymmetry in Fiscal Federalist Relations .......................................... 16

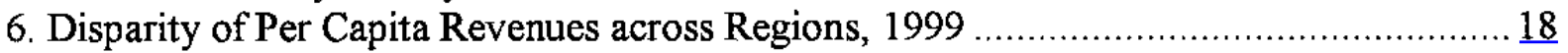

Boxes

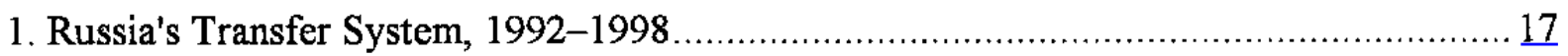

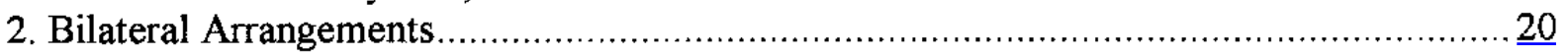

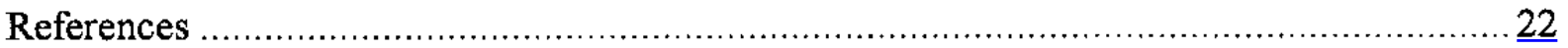




\section{INTRODUCTION}

Russia inherited from the Soviet Union an economic structure that was geographically highly unbalanced. Capital accumulation and industrial location were a result of a concerted government policy to locate key industries in a small number of regions. But even after the collapse of the Soviet Union, the gap between more prosperous regions, including Moscow and St. Petersburg, and less developed ones, has not been reduced. Actually, the gap has widened during the last decade of transition.

The imbalances in economic conditions across Russia's 89 regions have naturally produced a variety of very distinct fiscal situations and policies. ${ }^{2}$ Moreover, disparities in per capita revenue collections have increased steadily during the transition. In facing a complicated web of rising horizontal imbalances, all regions in Russia have been broadly divided into two groups: a small group of "donor" regions that make a positive net contribution to the center, and the rest, the more economically depressed regions which are recipients of transfers and subsidies. ${ }^{3}$ In order to deal with disparities among regions, horizontal imbalances have become a focus of the transfer policies initiated by the central government.

There are many instances where transfers are explicitly or implicitly targeted to deter regional imbalances. As Ahmad and Craig (1997) note, "... national governments may wish to ensure that citizens in different regions and localities have access to a certain modicum of publicly provided services." The horizontal imbalances in fiscal capacity can be addressed by equalization transfers from the center (as in Australia, Canada and Denmark) or between regions (as in Germany and Scandinavian countries). In all these countries, explicit interregional transfers rules are largely motivated by equity and solidarity considerations.

In this paper we offer a theoretical treatment of various transfer rules between different regions and outline the principle of partial equalization. This principle implies that, the more depressed regions should be subsidized by more advantageous regions, though the burden on the more prosperous regions should not be excessive. Thus, one may aim to reduce the gap between

\footnotetext{
2 The Russian federation is made up of 89 regions consisting of 21 ethnically defined republics, 49 oblasts (provinces), the Jewish Autonomous Oblast, 6 krais (territories), 10 autonomous okrugs (areas), and 2 metropolitan cities (Moscow and St. Petersburg). These are collectively referred to as 89 "subjects of the federation".

${ }^{3}$ Lavrov et al. (2001) argue that federal funds are distributed to regions not only in the forms of transfers but also as direct expenditures (in the form of wage payments to federal employees, funding of federal programs, etc.), which are at least as important as other forms of financial aid provided to regions. Accounting for federal budgetary expenditures can often obfuscate the distinction between donor and subsidy regions. In this paper, however, we abstract from federal budgetary expenditures in regions.
} 
donors and subsidy recipients but the gap should not be eliminated or even made too small, in part, due to political economy considerations. ${ }^{4}$

Le Breton and Weber (2000) analyze different compensation schemes that prevent a threat of secession by different regions in a country. They show that under certain conditions, there exist secession-proof compensation schemes which entail a degree of partial equalization. In this paper, we do not explicitly model the threat of secession by different regions in a country. Instead, we focus on different types of transfers schemes that meet the government's objectives of reducing horizontal balances while implicitly taking into account political economy considerations. The theoretical rules are applied to the Russian case to assess the extent to which transfer policies adopted during the transition deviated from the principle of partial equalization.

The paper is organized as follows. In the next section we provide a brief description of regional disparities in Russia. Section III focuses on the horizontal imbalances among Russian regions. Section IV is devoted to the theoretical analysis of general transfer rules. Section V examines the practical aspects of the federal transfers' policy in Russia and to what extent they adhere to the theoretical rules examined in the previous section. Section VI briefly discusses the impact of political factors on transfer policies of the central government. We conclude the paper with some final remarks.

\section{RUSSIA: THE STORY OF REgIONAL DISPARITIES}

The economic structure of the Soviet Union was characterized by a very high degree of geographical concentration. Capital accumulation and industrial location were a result of a concerted government policy to locate key industries-such as steel and energy-intensive heavy machine building - in a handful of regions. Such patterns of regional concentration appear to have increased during the 1990s in the Russian Federation. For instance, in 1995, 75 percent of metals and 74 percent of fuels were produced in just 10 regions. ${ }^{5}$ Oil and gas come mostly from the two Siberian regions of Khanti-Mansiiskiy Autonomous Okrug (AO) and YamaloNenetskiy AO, that jointly produce four-fifths of Russia's oil (Freinkmen et al (1999)). More than 50 percent of machinery was also produced in the top 10 regions. As a result, most of the country's GDP is produced in a small number of regions. It was estimated that in 1995, the top ten regions produced about 44 percent of the country's total GDP, with Moscow city alone accounting for 13.1 percent.

\footnotetext{
${ }^{4}$ It is interesting to note that due to the heavy economic burden imposed by the unification of East and West Germany, the transfer system used there exhibited a degree of over-equalization. Spahn and Fottinger (1997) note that while the fiscal capacity of poorer former East German provinces increased after the transfers, the contribution paid by rich former West German states reduced their fiscal capacity below the average.

${ }^{5}$ Russia Economic Trends (1997).
} 
At the same time, a number of regions are small, underdeveloped, often located in remote parts of the country, and have a long history of dependence on federal assistance. The absence of a diversified industrial structure in many regions and the resultant dependence on a single sector of economic activity has left them particularly vulnerable to the liberalization of prices and trade following the transition to a market economy.

Many of the industrial-location decisions made in the Soviet Union were non-sustainable in a market competitive environment and the collapse of the military-industrial complex also contributed to the sharp variation in industrial contraction across regions. For example, if average regional output contracted by over 57 percent in real terms between 1990 and 1996, the drop in individual regions ranged from 87 percent in Aginskiy-Buryatskiy Autonomous Okrug to just 15 percent in Yamalo-Nenets (Freinkmen et al (1999)). The dramatic variation in the proportion of loss-making enterprises across regions and the pattern of investment flows to regions have also accentuated the pattern of differentiation.

This variation in economic performance and specialization translated into sharp interregional differences in the standards of living, with unemployment levels and income inequality varying significantly across regions. Table 1 shows that the coefficient of variation for per

Table 1

\begin{tabular}{lcccc}
\hline \multicolumn{5}{c}{$\begin{array}{c}\text { Regional Economic Disparities, 1992-1997 } \\
\text { (Per Capita GRP in Roubles) }\end{array}$} \\
\hline Year & Mean & $\begin{array}{c}\text { Coefficient of } \\
\text { Variation }\end{array}$ & Minimum & Maximum \\
\hline 1992 & 123.5 & 0.875 & 19.4 & 786.0 \\
\hline 1994 & $3,712.3$ & 0.746 & 618.1 & $20,909.6$ \\
\hline 1995 & $9,487.9$ & 0.836 & $1,881.9$ & $59,004.5$ \\
\hline 1996 & $13,554.6$ & 1.039 & $2,628.0$ & $108,443.5$ \\
\hline 1997 & $13,887.9$ & 0.976 & $2,608.6$ & $102,262.1$ \\
\hline
\end{tabular}

Source: Dabla-Norris, Martinez-Vasquez, and Norregaard (2001).

capita gross regional product (GRP) increased across regions over the 1992-1997 period. By individual regions, the City of Moscow received 20 percent of all income in 1995, but it represented only 7 percent of the population (Martinez-Vazquez (2000)). The incidence of poverty has also been regionally concentrated, with three quarters of the residents of Tuva Republic classified as poor, as compared to only 19 percent in Moscow.

In summary, Russia's 89 regions exhibit dramatic variation in economic structure and performance - a pattern that appears to have been exacerbated in the post communist period. Economic activity, wealth, and tax burdens are increasingly concentrated in a handful of regions 
(notably Moscow), while many regions remain economically depressed, with high unemployment, unprofitable enterprises, and a growing reliance on federal transfers. These interregional differences, rooted in geographical variation and inherited economic structures, have led to a diversity of regional economic and political interests and posed a significant challenge to the evolving system of intergovernmental relations.

Naturally, variations in regional economic conditions have translated into a divergence in their fiscal situations and policies. Russia's regions during the early years of transition were broadly divided into two groups: a minority of "donor" regions that contribute more to the center than they got back, including Moscow, St. Petersburg and eight other well-off regions; and the remainder subsidy recipient regions - that were largely economically depressed, ran large deficits and were heavily dependent on federal aid. ${ }^{6}$

Disparities in per capita revenue collections have increased steadily during the transition. As shown in Table 2, the coefficient of variation for revenue collections across regions (inclusive of the federal share of all revenues) increased from 0.68 percent in 1993 to over 1.2 percent in 1998 , with the five highest collection regions accounting for over 40 percent of all revenue collections in 1998. With respect to own revenues (exclusive of the federal share), the twenty highest revenue collection regions represented over 66 percent of all subnational revenue collections in 1998 (Table 3). As expected, the high collection regions were also the richest regions, although many of them also accounted for the largest share of arrears to the federal budget and were the main holders of extra budgetary funds that do not have to be shared. In fact, while all the main taxes have to be shared between the regions and the federal government in fixed proportions dictated by law, as will be discussed below, regions varied greatly in the share of taxes left with their budgets.

Regional budget spending in Russia also shows a marked variation. For instance, the best-off region in 1993 spent close to 12 times more in per capita expenditures than the worst-off region, with the gap widening to over 24 times in 1998, as shown in Table 4 . The coefficient of variation for expenditures per capita across the regions increased by 46 percent over this period. Regions also vary in their allocation of resources across different categories of spending, with some regions spending significantly higher proportions of their budgets on

\footnotetext{
${ }^{6}$ In 1996, the most heavily subsidized regions were Chechnya (where transfers financed 93 percent of expenditures), Dagestan (61 percent), and Tuva (51 percent) (OECD (2000)). Some natural resource rich regions that are remote from the European hinterland, such as Sakha, also continue to rely excessively on federal subsidies to provide food, energy, and other supplies.
} 
Table 2

Measures of Regional Fiscal Disparities: Per Capita Regional Revenue Collections, 1993-1998 (in thousands of Rubles)

\begin{tabular}{rrrrr}
\hline Year & Mean & CV & Minimum & \multicolumn{1}{c}{ Maximum } \\
\hline 1993 & 149.71 & 0.68 & 0.01 & 566.24 \\
1994 & 573.75 & 0.89 & 33.77 & $2,993.17$ \\
1995 & $1,296.44$ & 0.86 & 88.45 & $7,201.64$ \\
1996 & $1,879.43$ & 1.13 & 132.71 & $14,871.69$ \\
1997 & $2,509.32$ & 1.42 & 162.52 & $28,200.82$ \\
1998 & $2,284.52$ & 1.21 & 294.89 & $21,167.24$ \\
\hline
\end{tabular}

Source: Dabla-Norris, Martinez-Vasquez, and Norregaard (2001)

Table 3

Concentration of Total Revenue Collections Among Oblast: Share of Total Revenues Collected by Selected Regions, 1993-1998

\begin{tabular}{lccccccc}
\hline & 1993 & 1994 & 1995 & 1996 & 1997 & 1998 & $\begin{array}{c}\text { Population } \\
\text { 1998 } \\
\text { (Millions) }\end{array}$ \\
\hline Five highest collection regions & 27.9 & 30.5 & 30.8 & 31.4 & 33.9 & 32.5 & 20.0 \\
Ten highest collection regions & 43.0 & 44.7 & 45.2 & 46.0 & 48.9 & 47.8 & 33.5 \\
$\begin{array}{l}\text { Twenty highest collection } \\
\text { regions }\end{array}$ & 62.6 & 64.5 & 64.3 & 65.1 & 66.5 & 66.2 & 52.9 \\
\hline
\end{tabular}

Source: Dabla-Norris, Martinez-Vasquez, and Norregaard (2001) 
Table 4

Measures of Horizontal Fiscal Imbalance: Per Capita Regional Expenditures, 1993-1998

(Roubles)

\begin{tabular}{ccccc}
\hline Year & Mean & $\begin{array}{c}\text { Coefficient of } \\
\text { Variation }\end{array}$ & Minimum & Maximum \\
\hline 1993 & 219.7 & 0.775 & 100.6 & 1189.2 \\
1994 & 959.7 & 1.191 & 359.8 & 8000.7 \\
1995 & 1904.9 & 1.023 & 720.2 & 13004.3 \\
1996 & 2835.7 & 1.067 & 1050.3 & 16521.1 \\
1997 & 3730.1 & 1.187 & 1336.7 & 30543.5 \\
1998 & 3184.4 & 1.022 & 1121.5 & 22559.8 \\
\hline
\end{tabular}

Source: Dabla-Norris, Martinez-Vasquez, and Norregaard (2001)

subsidies for housing and utilities. Recent studies of the determinants of expenditures across regions have found that even controlling for fiscal resources, economically depressed regions tended to spend less on subsidies than the wealthier regions.

The issue of regional disparities and horizontal imbalances in fiscal capacity is addressed by the central government through revenue sharing and transfer policies, the theoretical aspects of which we study in the next section.

\section{MODEL}

\section{A. Environment}

We examine a model with one country that consists of $K$ heterogeneous regions. ${ }^{7}$ The regions differ on a variety of characteristics, such as capital accumulation, economic performance, industrial base, wealth of mineral resources, that determine the revenue base of each region. We denote the revenue base of region $k$ by $R_{k}$ and its expenditure needs by $E_{k}$, where $k=1,2, \ldots, K^{8}$ The difference between $R_{k}$ and $E_{k}$, the net revenue, is denoted by $\alpha_{k}{ }^{9}$ :

$$
\alpha_{k}=R_{k}-E_{k}
$$

\footnotetext{
${ }^{7}$ A similar model in a different framework has been considered by Dr' eze (1993).

${ }^{8}$ The revenue base of each region can be regarded as the "own revenues" of that region.

${ }^{9}$ Notice that actual revenues collected could differ from the revenue base, which can be interpreted as the revenue base.
} 
The gap in net revenues represent horizontal imbalances between different regions, with a higher value of $\alpha$ indicating a more advantageous region. A net revenue gap may be positive (denoting a surplus) or negative (denoting a deficit). Regions with deficits experience greater fiscal pressures which are assumed to at least, partially be relieved by the central government. For simplicity of presentation we assume that surpluses are ordered such that

$$
\alpha_{1}>\alpha_{2}>\ldots>\alpha_{K}
$$

That is, the surplus of regions is descending from region 1 to $K$, such that no region has a zero surplus (or deficit) and let $k^{*}$ be the region with the smallest surplus. It would immediately follow that the region $k^{*}+1$ has the smallest fiscal deficit:

$$
\alpha_{1}>\ldots>\alpha_{\mathbf{k}^{*}}>0>\alpha_{\mathbf{k}^{*}+1}>\ldots \alpha_{K}
$$

Now let us turn to the role of the central government. We assume that the central government assigns a special budget $B$ to address disparities and horizontal imbalances across regions. For simplicity, we do not discuss how the value of $B$ is determined and assume that it is given. ${ }^{10}$ One can think of B as an exogenous tax or revenue sharing target that is distributed according to some pre-determined scheme. In order to address existing fiscal imbalances across regions, the central government determines a two-step policy: first, it determines which regions are donors and which are to be the recipients of federal aid. Second, the central government determines the size of donors' contributions and the value of federal transfers for each of the aid recipients. The budget is assumed to be balanced in the sense that the total sum of the special budget $\mathrm{B}$ and all donors' contributions equals the total value of aid provided to the recipient regions.

Note that the ordering of the regions from the wealthiest to the poorest substantially simplifies the first part of the government policy of identifying donors and recipients. In effect, the government simply determines a cut-off index $l$, where $1 \leq l<K$, such that all regions $k$ with $k \leq l$ are donors whereas all regions with a deficit are recipients. It is natural to assume that only regions with surpluses can be considered as donors. Therefore, $l$ does not exceed the cutoff value $k^{*}$, i.e. $l \leq k^{*}$. However, since we do not require that every region with a surplus to be a donor, it follows that regions with small surpluses can be exempt from participation in the transfer program. Given the set of $l$ donors, the central government determines a uniform rule that specifically identifies a share $t_{k}$ such that every donor $k \leq l$ contributes a share $t_{k} \alpha_{k}$ of its surplus. The regions with a deficit (those with $k^{*}<k \leq K$ ) receive a transfer payment of $-t_{k} \alpha_{k}>0$.

${ }^{10}$ In reality, the size of $B$ may depend upon existing tax sharing arrangements between the center and regions. For instance, if $B$ is funded through shared federal taxes, a smaller number of donors could imply a smaller pool of funding for equalization transfers. 
The balance budget condition for the central government requires:

$$
\sum_{k=1}^{l} t_{k} \alpha_{k}+\mathrm{B}+\sum_{k^{*}+1}^{K} t_{k} \alpha_{k}=0
$$

We assume that, $\mathrm{B}$ is independent of regional revenues, and as is the case in many developing countries, regions face an aggregate deficit and that the total special budget, B, does not cover the total deficit $\mathrm{D}$, i.e.,

$$
D=\sum_{k=1}^{K} \alpha_{k}<-B<0
$$

\section{B. The Uniform Transfer Rule}

Consider first the case where the central government designates all $k^{*}$ regions with a surplus as donors and uses a uniform transfer rule, such that all regions contribute the same shares, i.e., $t_{k}=t$. Equation (1) can then be written as:

$$
t \sum_{k=1}^{K} \alpha_{k}+B=t D+B=0
$$

The value of the redistributive parameter $t\left(k^{*}\right)$ is then given by:

$$
t\left(k^{*}\right)=-\frac{B}{D}
$$

Equation (2) implies that $t$ is a positive number between 0 and 1 . This conclusion yields the important principle of partial equalization. It states that, on one hand, poorer regions should be subsidized (indeed, the rate $t$ is positive and some equalization does take place). On the other hand, the fact that the value of $t$ is less than 1 guarantees that fiscal gaps between regions are not completely eliminated. That is, if a region $k$ has a higher surplus than region $m$, i.e., $\alpha_{k}>\alpha_{m}$, then even after the transfer, the fiscal gap still persists as $(1-t) \alpha_{k}>(1-t) \alpha_{m}$. To summarize, this principle suggests that gaps between regions should be reduced but not completely eliminated. It is also important to note that for any two regions $k$ and $m$, with $k<m$ we have

$$
\alpha_{k}\left(1-t\left(k^{*}\right)\right)>\alpha_{m}(1-t(m))
$$

The uniform rule with $k^{*}$ donors, therefore, satisfies the condition of ranking invariance in the sense that the ranking of the regions' surpluses and deficits is not altered by the transfer policy. 
If region $k$ has a higher surplus than region $m$, the net surplus of region $k$ would still be higher than that of region $m$. Income invariance seems to be a reasonable and quite modest requirement on transfer policy. Indeed, it would be very difficult for the central government to convince a region $k$, that has a greater surplus than region $m$, to be engaged in transfer policy that would reverse the order of the net surpluses between these two regions.

\section{The $\bar{\alpha}$-Transfer Rule}

Consider now a government transfer policy that designates regions with small surplus neither as donors nor as transfer recipients. In other words, in addition to donors and recipients, the government introduces a third intermediate class of regions that do not belong to either of two groups. The government, thus, determines a threshold value, $\bar{\alpha}$, such that all the regions that satisfy

$$
0<\alpha_{k}<\bar{\alpha}
$$

are exempt from their contribution to the transfer program. Let $l<k^{*}$ be such that

$$
\alpha_{l+1}>\bar{\alpha} \geq \alpha_{l}
$$

Then regions $1,2, \ldots, l$ are designated as donors, whereas regions $k^{*}, k^{*}+1, \ldots, K$ are the transfer recipients. In this case, the balanced budget condition can be written as:

$$
t \sum_{k=1}^{l} \alpha_{k}+t \sum_{k^{*}+1}^{K} \alpha_{k}+B=0
$$

The value of the parameter $t=t(\bar{\alpha})$ is given by:

$$
t(\bar{\alpha})=-\frac{B}{D-\sum_{k=l+1}^{k^{*}} \alpha_{k}}
$$

Since $\mathrm{D}<-\mathrm{B}$, the value of $t(\mathrm{l})$ is again positive but is lower than 1 . It is worth pointing out that the function $t(\bar{\alpha})$ is decreasing in $\bar{\alpha}$. Indeed, the higher the cut-off value $\bar{\alpha}$, the smaller the number of donors. A smaller number of donors would, in turn, reduce the size of transfer payments.

Since $0<t(\bar{\alpha})<1$, the principle of partial equalization holds in this case as well. The disadvantageous regions receive transfers while advantageous regions keep a part of their surpluses. 
Let us now turn to the ranking invariance of surpluses and deficits. Obviously, this is preserved within each of three groups: donors, recipients as well as the intermediate regions. Since all recipients have a net deficit even after transfers, the only possibility for the ranking to be reversed is when the donor with the lowest surplus has a lower net surplus than one of the intermediate regions. This situation cannot occur when the following inequality is satisfied:

$$
\alpha_{l}(1-t(\bar{\alpha}))>\alpha_{l+1}
$$

By substituting the expression for $t(\bar{\alpha})$ from $(7)$, we obtain

$$
\alpha_{l}\left(1+\frac{B}{D-\sum_{k=l+1}^{k^{*}} \alpha_{k}}\right)>\alpha_{l+1}
$$

or

$$
0<B<\left(1-\frac{\alpha_{l+1}}{\alpha_{l}}\right)\left(\sum_{k=l+1}^{k^{*}} \alpha_{k}-D\right)
$$

The intuition behind this result is quite simple. There is no a possibility of ranking reversal if the special budget is sufficiently small. In this case, transfers are not sufficiently large to alter the ranking of regions' surpluses. However, if the special budget is relatively large, then the implementation of the uniform proportional policy could be problematic in light of potential political economy considerations. Let us turn therefore to the case where the central government may abandon the uniform transfer rule.

Note that, the uniform transfer rule examined in the previous subsection, is in fact, a special case of the $\bar{\alpha}$-rule for $\bar{\alpha}=0$. Indeed, if $\bar{\alpha}$ is equal to zero, all regions with a positive surplus will be designated as donors.

\section{General Transfer Rule}

Consider now a transfer rule that assigns different rates to different regions. As in the previous section, the government determines the threshold value, $\bar{\alpha}$, such that all regions with a positive surplus below $\bar{\alpha}$ would not be required to participate in the transfer program. Let $l$ again denote the region with the smallest surplus among the designated donors. The government then establishes a transfer rate for donors, $t_{1}, \ldots, t_{l}$ and for recipients $t_{k^{*}+1}, \ldots, t_{K}$. We impose a progressivity condition both for donors.

$$
t_{1}>t_{2}>\ldots>t_{l}
$$


and for recipients

$$
t_{k^{*}+1}<t_{k^{*}+2}<\ldots<t_{K}
$$

From the balanced budget condition (1) we obtain

$$
\sum_{k=1}^{l} t_{k} \alpha_{k}+\sum_{k=k^{*}+1}^{K} t_{k} \alpha_{k}+B=0
$$

To examine the restrictions that the principle of partial equalization and ranking invariance impose on the values of ranking shares, note first that all values $t_{k}$ would be chosen between 0 and 1. In addition, the condition of ranking invariance for donors implies that:

$$
\alpha_{1}\left(1-t_{1}\right)>\alpha_{2}\left(1-t_{2}\right)>\ldots \alpha_{l}\left(1-t_{l}\right)
$$

or the series of inequalities

$$
t_{1}<1-\frac{\alpha_{1}}{\alpha_{2}}\left(1-t_{2}\right), t_{2}<1-\frac{\alpha_{3}}{\alpha_{2}}\left(1-t_{3}\right), \ldots, t_{l-1}<1-\frac{\alpha_{l}}{\alpha_{l-1}}\left(1-t_{l}\right)
$$

Similar conditions for recipients imply:

$$
\alpha_{k^{*+1}}\left(1-t_{k^{*+1}}\right)>\alpha_{k^{*}+2}\left(1-t_{k^{*}+2}\right)>\ldots>\alpha_{K}\left(1-t_{K}\right)
$$

or

$$
t_{k^{*}+1}>1-\frac{\alpha_{k^{*}+2}}{\alpha_{k^{*}+1}}\left(1-t_{k^{*}+2}\right), t_{k^{*}+2}>1-\frac{\alpha_{k^{*}+3}}{\alpha_{k^{*}+2}}\left(1-t_{k^{*}+3}\right), \ldots, t_{K-1}>1-\frac{\alpha_{K}}{\alpha_{K-1}}\left(1-t_{K}\right)
$$

Finally, order invariance implies that

$$
\alpha_{l}\left(1-t_{l}\right)>\alpha_{l+1}
$$

or

$$
t_{l}<1-\frac{\alpha_{l+1}}{\alpha_{l}}
$$


The inequalities (9)-(12) determine the set of values for transfer shares under a general transfer rule. Notice that in contrast to the general transfer rule, the uniform transfer rule does not introduce incentives to misrepresent the region's budgeted $\alpha_{K}$. Setting differential tax rules, however, requires information from regions who may be net contributors to $\mathbf{B}$, thereby creating incentives for misreporting.

\section{Federal Government Responses to Regional DIVERSITY AND DISBURSEMENT Pattern of Federal Transfers}

Since the beginning of the transition, the federal government has attempted to accommodate the extreme economic and fiscal differentiation of regions discussed above using a combination of policies, including tax assignments and intergovernmental transfers. ${ }^{11}$ In this section we examine the disbursement pattern of federal transfers and revenue sharing arrangements in relation to some of the theoretical principles outlined in the previous section.

The initial phase of transition (prior to 1994) was characterized by ever-changing and individually customized revenue assignments for each regional government in the annual budget (non uniform $t \alpha$ ). The basic rule adopted was to use different combinations of the main federal taxes (the VAT, personal income tax, enterprise profits tax and excises) to "regulate" the revenues of regional governments. Sharing rates were customized so that individual subnational governments had just enough revenues to finance their "minimum" expenditure budget. ${ }^{12} \mathrm{~A}$ forecast of subnational government own revenues were subtracted from the minimum expenditure budgets to arrive at the gap to be financed with revenue sharing. For poorer regions with modest tax bases, and where the retention of 100 percent of taxes collected within their territory was insufficient to finance the minimum expenditure budget, the remaining gap was financed through "subventions" or lump-sum transfers from the center (B in our model).

The practice of setting differential rates for regional deductions from federal taxes represented a deviation from the uniform transfer rule described above. For instance, in 1993, the share of federal axes transferred to consolidated regional budgets varied from 100 percent for Tartarstan, 54.6 percent for the wealthy cities of Moscow and St. Petersburg to 45 percent for other regions

${ }^{11}$ Intergovernmental transfers in Russia can be divided into two general categories: equalization transfers (since 1994, the Fund for Financial Support of Regions (FFSR)) and other transfers. The size of these other transfers in Russia during the 1994-98 period in some years exceeded the funding of the FFSR. A large share of the other transfers took the form of "mutual settlements", which included negotiated injections of funds, compensation for central government programs and mandated emergency grants, and other forms of non-budgeted support.

${ }^{12}$ See Dabla-Norris, Martinez Vazquez and Norregaard (2001) for details. 
(Table 5) ${ }^{13}$ In essence, while the wealthier regions were allowed to retain a larger share of federal taxes collected within their territory, revenue sharing arrangements varied greatly even among the subset of wealthy regions.

At the same time, the share of federal aid in total revenues also showed a marked variation (Table 5). Financial aid to regions was provided through a variety of mechanisms: equalization transfers, mutual settlements, subsidies and grants, and budget loans. Between the years 1992-1994, federal budget transfers to regions, increased from 1.7 to 3.8 percent of GDP or 20 percent of regional revenues. More importantly, non-transparent transfers, such as mutual settlements and subsidies to Moscow accounted for over 80 percent of all federal financial aid to regions. While the overall size of federal equalization transfers remained quite small, they represented a significant source of revenues for many of the economically depressed regions. ${ }^{14}$ For instance, for the 20 least developed regions in Russia, federal transfers accounted for 50-60 percent of subnational revenues in 1999 (OECD (2000)).

Reforms undertaken since 1994 have brought about greater uniformity to revenue sharing and expenditure arrangements between the federal government and the regions. A new system of formula-based equalization transfers the Fund for Financial Support of Subjects of the Russian Federation (FFSR) was introduced (see Box 1). For instance, Lavrov et al (2001) note that by 1996-98, the number of donor regions, for which the amount of taxes collected in their territory and credited to the federal budget exceeded the amount of financial transfers received, increased to 30 (out of 89 subjects of the federation). ${ }^{15}$

${ }^{13}$ In addition, actual revenue sharing between the federal government and regions has often differed significantly from the statutory rates stated in the law.

${ }^{14}$ In 1998 , they represented close to 2 percent of GDP and less than 14 percent of total subnational revenues.

${ }^{15}$ The remaining 59 regions were either recipients over the entire period or were donors in some years. 
Table 5

Indicators of Asymmetry in Fiscal Federalist Relations

\begin{tabular}{lcccc}
\hline & \multicolumn{2}{c}{$\begin{array}{c}\text { Share of federal aid } \\
\text { in total regional revenues } \\
\text { (percent) }\end{array}$} & $\begin{array}{c}\text { Share of taxes transferred to } \\
\text { consolidated regional budgets } \\
\text { (percent of total tax collections) }\end{array}$ \\
& 1993 & 1998 & 1993 & 1998 \\
Regional Average & 18.1 & 13.15 & 62.9 & 62.9 \\
& & & & \\
$\begin{array}{l}\text { Tartarstan, Bashkortostan, and } \\
\text { Sakha }\end{array}$ & 0 & 17.2 & 100.0 & 84.3 \\
$\begin{array}{l}\text { Other Republics } \\
\text { Oblasts and krays }\end{array}$ & 47.0 & 35.6 & 65.6 & 70.5 \\
$\begin{array}{l}\text { Cities of Moscow and St. } \\
\text { Petersburg }\end{array}$ & 17.6 & 14.4 & 62.2 & 68.1 \\
Autonomous oblast and oknugs & 10.6 & 1.0 & 54.6 & 45.3 \\
$\quad \begin{array}{l}\text { Of which } \\
\quad \text { Oil and gas-producing }\end{array}$ & 29.0 & 7.2 & 50.3 & 69.1 \\
Other & 5.2 & 3.4 & 49.1 & 68.7 \\
\hline
\end{tabular}

Source: OECD (2000)

The explicit economic rationale for a majority of center-region transfers since 1994 has been to reduce horizontal imbalances of regions. Empirical analysis of the effectiveness of equalization transfers by Le-Houerou and Rutkowski (1996) and Martinez-Vazquez and Boex (1997), however, suggests that federal transfers, for the most part have not been equalizing. This is particularly true in the case of non-FFSR transfers, which represented over 90 percent of all financial aid to regions in 1993. 


\section{Box 1. Russia's Transfer System, 1992-1998}

During 1992-1994, the bulk of all transfers were negotiated "subventions" to those regions for which own revenues and shared revenues were insufficient to fund their minimum expenditure budget. In 1994, the Russian government introduced a new system of equalization transfers, the Fund for Financial Support of the Regions (FFSR). This had two "windows". The first window, called "Regions in Need of Financial Assistance", was designed to equalize revenue availability across regions. The second window, called "Regions in Need of Additional Financial Assistance", was designed to provide additional funding to regions with expenditure needs not covered by other financing sources, including the first window.

In the early years of transition, total funding for the FFSR was not fixed but determined annually in the budget and divided between the two windows. For 1994, total funding for the FFSR was 22 percent of the federal share of VAT collections; for 1995, 27 percent of federal VAT collections; for 1996 and 1997, 15 percent of all federal tax collections except for tariff revenues; and for 1998, this was lowered to 14 percent (Dabla-Norris, Martinez-Vazquez, and Norregaard (2000)).

The first window of the FFSR equalized revenues across regions by comparing actual revenues per capita for the most recent year for which data were available in each region, to the average revenues per capita in one of three groups of regions (the Northern territories, the Far East and the rest of the country) based on similarities in the cost of living. Regions with per capita revenues below some percent of the group average were entitled to an equalization transfer. The transfer actually received was an apportionment of the available funds among all the regions entitled to transfers. The second window of the FFSR estimated expenditure needs for each region by adjusting expenditures (actual disbursed expenditures and not a measure of expenditure needs) in a base year for all changes in legislation in the intervening years. Those regions with expenditures exceeding revenues plus transfers from the first window were entitled to a transfer and the available funds apportioned among all the regions entitled to a transfer.

While the FFSR system represented a significant improvement over the previous system, it had several shortcomings. First, its limited and variable funding reduced the ability for equalization and generated budgetary uncertainty for subnational governments. Second, its outcomes were to subject to political negotiations. Third, its formula (the manner in which variables were computed) was changed frequently, contributing to revenue unpredictability for regional governments. Finally, the methodology employed past achieved levels of revenue and expenditures as primary criteria for allocation of transfers, thereby, undermining incentives to improve fiscal performance at the subnational levels (OECD 2000). 
In general, empirical analysis suggests that while federal transfers exacerbated regional revenue inequality in 1994, they appear to have somewhat reduced it in 1996 and 1997 (Freinkmen et al (1999) and Dabla-Norris, Martinez-Vazquez and Norregaard (2000)) and, thus, at least partially, reestablished the principle of partial equalization. In addition, while the impact of FFSR and other transfers in reducing per capita expenditure disparities across regions has been limited, there is some evidence to suggest that transfers have been increasingly equalizing tax capacity and expenditure needs across regions (Table 6).

If partial equalization is not the only determinant of the patterns of redistribution, what explains why some regions obtained larger amounts of federal aid than others? Recent empirical analysis suggests that while equity considerations have played an increasingly important role, the major motives in the past have been political in nature. Treisman (1996) and 1998) and others have remarked on the important role that separatist demands have played in the actual flow of fiscal resources between the center and the regions in Russia. He found that regions that demonstrated the capacity and resolve to threaten economic or constitutional order were rewarded with larger fiscal transfers and tax benefits.

Table 6

Disparity of Per Capita Revenues across Regions, 1999

\begin{tabular}{lcc}
\hline & $\begin{array}{c}\text { Before } \\
\text { equalization }\end{array}$ & $\begin{array}{c}\text { After } \\
\text { equalization }\end{array}$ \\
\hline $\begin{array}{l}\text { Richest to poorest } \\
\text { Gini index of }\end{array}$ & 90 & 20 \\
& 0.39 & 0.33 \\
\hline
\end{tabular}

Source: Ministry of Finance

\section{Political factors in Decentralization}

In order to explain the deviation from the uniform transfer rule during the early years of transition we need to examine the political factors in decentralization. The process of the reform of the system of intergovernmental relations in Russia has been foremost a political process. The relevance of politics in the Russian federation is undoubtedly related to its vast territory, significant regional disparities in industrial development and resource endowments, and its ethno linguistic diversity. These factors exerted strong centrifugal forces on the country.

The Russian Federation was essentially created out of a process of disintegration of the Soviet Union when Russia and other former Soviet republics refused to remit tax revenues to the Soviet government in Moscow, proclaimed that their laws took precedence over Soviet laws 
and ultimately declared themselves independent. This process set a precedent for many of the autonomous republics in Russia also to declare their independence or to assert high degrees of autonomy (Teague (1996)). The assertiveness of the regions, especially the ethnic republics, to ensure a measure of autonomy for themselves intensified during 1992-1993, with up to 30 regions withholding their contribution to the federal budget and demanding special tax regimes or federal subsidies (Wallich (1994)) ${ }^{16}$ These forces gained momentum, often leading to separatist demands and open opposition to federal government policies, at a time when the federal government attempted to unilaterally shift expenditure responsibilities and mandates to regional governments, without providing adequate funding.

In response to regional opposition and centrifugal forces, the federal government appears to systematically have offered greater advantages and privileges to the "difficult" regions. ${ }^{17}$ The federal government, empowered by the 1993 constitution, entered into a series of bilateral, "special-channel" arrangements with the regions in an attempt to balance regional objectives that conflicted with national interests.

The regions, first based on ethnic claims, and later simply on threats and demands, bargained for and obtained preferential fiscal treatments (see Box 2). At the same time, demands from poorer regions emerged for increased regional redistribution and the federal government was pressed to continue to fund a wide array of goods and services that it had earlier sought to offload on the regions. This type of response created an asymmetric federalism (Wallich (1994)), and explains the use of non-uniform transfers between the center and regions during the early years of transition.

${ }^{16}$ The regions that stopped or greatly reduced remittances to the federal government early in 1992 included the ethnic republics of Tatarstan, Chechnya, Sakha (Yakutia) and Bashkortostan.

${ }^{17}$ Shliefer and Treisman (2000) note that, "In essence, the federal government appeased regions that threatened political or economic stability-by declaring sovereignty, staging strikes, or voting for the opposition in elections-by allocating them larger transfers or tolerating their tax withholding". 


\section{Box 2. Bilateral Arrangements}

The basis for distinction between the 89 regions in Russia was the 1978 Constitution which adopted a nationality-based logic for distinguishing between units, with the ethnic republics enjoying the greatest autonomy from the federal government, followed by the other forms of republics, oblasts, metropolitan cities, oblasts, and autonomous okrugs. ${ }^{18}$

With the collapse of the Soviet Union, the status of regional-federal relations was embodied in the Federation Treaty of 1992, which attempted to institutionalize some of the informal bargaining that took place between the center and regions during this period. The Federation Treaty provided for greater regional administrative autonomy and participation in federal law-making for the republics, but krais and oblasts were denied this privilege. This asymmetry was eliminated in the 1993 Constitution which declared all subjects of the Federation equal with all entities receiving the right to develop their own legal systems, but granted the ethnic republics special rights such as the passing of their own constitutions and electing their own heads of government. However, ambiguity in Articles 71 and 72 of the Constitution concerning the division of powers between the federal government and regions, as well as provisions in the Constitution have allowed the federal authorities to enter into bilateral arrangements with separate regions.

Special arrangements, such as those granting exclusive rights over natural resources to the republics of Tatarstan and Bashkortostan signed in 1994, have often reflected political realities and compromises in face of strong regional opposition and centrifugal forces. These treaties, however, set a precedent that was picked up by other constituent units of the Russian Federation. Pressure from non-republic units opened the treaty process to oblasts and krais as well, resulting in a proliferation of treaties in the 1994-1998 period. In general, regional positions on federation issues and federal policies have been dominated by the "donor" versus "transfer recipients" divide. By 1997, 32 of the 89 subjects of the federation had signed such treaties, and by 1998 the total had reached 45 (OECD (2000)). The expanded use of bilateral treaties has resulted in a complex bargaining game, in which all regions have an incentive to deviate from federal laws and obligations in order to extract concessions from the center. Differences in the bargaining power and relative credibility of the participants, however, have served to reinforce the pattern of asymmetric federalism that has emerged since independence.

${ }^{18}$ The territory of administrative units formed by the republics, oblasts, and autonomous okrugs covers 53 percent of the territorial area of Russia and includes 20 percent of the total population. 


\section{CONCLUDING REMARKS}

In this paper we examined the issue of increasing regional disparities and widening horizontal imbalances among the regions in the Russian Federation. The state planning policies of the former Soviet Union created a very uneven economic structure that produced a great variance in terms of capital accumulation, industrial production and revenue collection across the regions. The gap between more prosperous and less developed regions actually increased over the last decade.

During the early years of transition, federal transfers failed to achieve a degree of partial equalization and were largely non-uniform in nature. This was in large part due to political factors including the pervasiveness of bilateral negotiated arrangements between the federal and regional governments. In recent years, the move towards more uniform tax sharing arrangements and increasing reliance on systematic formula-based equalization transfers suggests that there has been a move to achieve a measure of partial equalization. 


\section{REFERENCES}

Ahmad, E., and J. Craig, 1997, "Intergovernmental Transfers," in Fiscal Federalism in Theory and Practice, ed. by T. Ter-Minassian (Washington: International Monetary Fund).

Dabla-Norris, E., J. Martinez-Vazquez, and J. Norregaard, 2002, Fiscal Decentralization and Macroeconomic Performance: The Case of Russia, Ukraine, and Kazakhstan, (IMF forthcoming).

Dreze, J., 1993, "Regions of Europe: A Feasible Status, to be Discussed," Economic Policy, Vol. 8 (October), pp. 265-307.

Freinkmen, L.M., D. Treisman, and S. Titov, 1999, "Subnational Budgeting in Russia: Preempting a Potential Crises," World Bank Technical Paper No. 452 (Washington: World Bank).

Lavrov, A.M., and A. Makushkin, 2001, The Fiscal Structure of the Russian Federation: Financial Flows Between the Center and Regions (New York: EastWest Institute).

Le Breton, M., and S. Weber, 2000, "The Art of Making Everybody Happy: How to Prevent a Secession?" IMF Policy Discussion Paper (Washington: International Monetary Fund).

Le Houerou, P., 1996, "Federal Transfers in Russia: Their Impact on Regional Revenues and Incomes," Comparative Economic Studies, Vol. 38 (Summer-Fall), pp. 21-44.

Martinez-Vazquez, J., and J. Boex, 1998, “A Methodology for Implementing Transfers to Depressed Regions in the Russian Federation," U.S. Government Technical Assistance Team, Moscow.

____, 2000, "Fiscal Decentralization in the Russian Federation: Main Trends and Issues," (Washington: World Bank).

Organization for Economic Cooperation and Development, 2000, Russian Federation (Paris).

Polishchuk, L., 1999, "Legal Initiatives in Russian Regions: Determinants and Effects," IRIS Working Paper No. (University of Maryland: Center for Institutional Reform and the Informal Sector).

Shliefer, A., and D. Treisman, 2000, Without a Map: Political Tactics and Economic Reform in Russia (Cambridge, Massachusetts: MIT Press).

Spahn, P., and W. Fottinger, 1997, "Germany" in Fiscal Federalism in Theory and Practice, ed. by Ter-Minassian (Washington: International Monetary Fund). 
Teague, E., 1996, "Russia and the Regions: the Use of Ambiguity," in Transformation from Below: Local Power and the Political Economy of Post-Communist Transitions, ed. by J. Gibson and P. Hanson (Cheltenham: U.K.).

Treisman, D., 1996, "The Political Economy of Intergovernmental Transfers in Post-Soviet Russia," British Journal of Political Science, Vol. 16, pp. 299-335.

_ , 1999, "Russia's Tax Crises: Falling Revenues in a Transitional Economy," Economics and Politics, Vol. 11, pp. 145-170.

Wallich, C., 1994, Russia and the Challenge of Fiscal Federalism, (Washington: World Bank). 